\title{
Türkiye'nin 1929 Dünya Ekonomik Krizine Karş1 Aldığı Mali ve Ticari Tedbirler
}

DOI: $10.26466 /$ opus. 931422

\author{
* \\ Nedim Sarıg̈̈zel $^{*}$ \\ * Öğr. Görevlisi Dr., Selçuk Üniversitesi,, Konya/Türkiye \\ E-Posta: nsariguzel@selcuk.edu.tr \\ ORCID: $\underline{\text { 0000-0002-9099-7005 }}$
}

\begin{abstract}
Öz
1929 Dünya Ekonomik Krizi, başta Amerika Birleşik Devletleri olmak üzere dönemin önemli güçlerini etkisi altına almıştır. Türkiye de bu krizden en az büyük devletler kadar etkilenmiştir. Ekonomi politikasın 1923-1930 döneminde özel sermayeyi destekleyerek kalkınmak üzerine inşa eden Türkiye, kriz ile birlikte devletin daha müdahaleci olduğu bir ekonomik modeli benimsemiştir. Atatürk döneminin denk bütçe, dengeli dış ödeme politikasına kriz döneminde de devam edilmiştir. Ancak bu dönemde genel ekonomik politika değişimine paralel olarak denk ve dengeli ekonomi hedefine ulaşma görevini devlet üstlenmiştir. Böylece devletin aldığı tedbirler vasıtasıyla krizle mücadele etmek adına Türk parasını korumak ve dış ödemeler dengesini sağlamak üzere çeşitli tedbirler alınmıştır. Hükümet kriz döneminde dış ticaret dengesini să̆lamak için, ihraç ettiğin kadar ithal et anlayışı ile hareket etmiştir. Ticari ilişkiler olan ülkelerle, imkânlar dâhilinde karşılıklı ve eşit miktarlı alışveriş yapmayı să̆layacak anlaşmalar yapılmıştır. Böylece kriz döneminin dış ticaret politikasını çeşitli kontenjan, takas ve kliring anlaşmaları oluşturmuştur. Türkiye'nin, almış olduğu bu tedbirler dâhilinde para, bankacıllı ve ticaret politikası ile vergi sistemi üzerinde önemli değişiklikler yapılmıştır. İkili ticari ilişkiler olan devletlerle yapılan anlaşmalar ile de bu değiş̧iklikler hayata geçirilmiştir. Böylece krizle mücadele adına daha korumacı bir politika benimsenmiştir.
\end{abstract}

Anahtar Kelimeler: Dış Ticaret, Ekonomi, 1929 Dünya Ekonomik Krizi, Mali Tedbirler, Ticari Tedbirler. 


\title{
Financial and Commercial Measures Taken by Turkey Against the World Economic Crisis of 1929
}

\begin{abstract}
The world economic crisis of 1929 affected important forces of the period, especially the United States. Turkey has been affected by this crisis as much as the major states. Turkey, which built its economic policy on development by supporting private capital in the period 1923-1930, adopted an economic model in which the state was more interventionist with the crisis. The equivalent budget and balanced foreign payment policy of the Atatürk period continued during the crisis period. But in this period, in parallel with the general change in economic policy, the state undertook the task of achieving the goal of an equal and balanced economy. In this way, various measures have been taken to protect Turkish money and ensure the balance of external payments in order to combat the crisis through the measures taken by the state. The government has acted with the understanding of imported meat as much as exported to ensure the balance of foreign trade during the crisis. Agreements have been made with countries with commercial relations that will allow mutual and equal exchange within the scope of opportunities. Thus, various quota, clearing and clearing agreements formed the foreign trade policy of the crisis period. Within the framework of these measures taken by Turkey, significant changes have been made to monetary, banking and trade policy and tax system. These changes have also been implemented through agreements with states that have bilateral trade relations. Thus, a more protectionist policy was adopted in the name of combating the crisis.
\end{abstract}

Keywords: World Economic Crisis Of 1929, Turkey's Economy, Financial Measures, Commercial Measures. 


\section{Giriş}

1929 yılında ortaya çıkan ekonomik kriz tüm dünyayı sadece o yıl için değil uzun bir dönem etkisi altına almıştır. Kriz, büyük sosyoekonomik ve kültürel değişimlerin yaşanmasına neden olacak kadar etkili olmuştur. Tüm dünyayı etkisi altına alan böylesine büyük çaplı bir krizden yeni kurulmakta olan ve kırılgan bir ekonomiye sahip olan Türkiye'nin etkilenmemesi mümkün değildi. Neticede kriz Türkiye'yi de kısa sürede etkisi altına almış ve geniş çaplı politika değişimine zorlayacak kadar etkilemiştir.

Türkiye'nin krize karşı aldığı tedbirlere geçmeden önce krizden ne ölçüde etkilendiğine bakacak olursak bunun dış ticaret açı̆̆ı ve para değeri üzerinden gerçekleştiğini görürüz. Çünkü dünya ekonomik krizi etkisini hammadde fiyatlarındaki büyük düşüşle göstermiş bu da Türkiye'nin ihraç ürünlerinin fiyatlarına olumsuz yansımıştır (Yerasimos, 1989, s.116). Böylece kısa sürede dış ticaret açığı ortaya çıkarken Türk Lirası yabancı paralar karşısında hızla değer kaybetmeye başlamıştır. Aslında bu süreçte Türkiye'nin yüksek oranda tarımsal ihracat beklentisi vardır. Ancak beklentinin aksine Türkiye'nin diş ticaret taahhütlerini karşılayacak üretim seviyesine ulaşamaması nedeniyle 1928-1930 döneminde Türk parasında değer kaybı hız kazanmıştır. Bu değer kaybında, 1929 yılında yaşanan kuraklığın etkisiyle üretimin düşmesi ve buna bağlı olarak ihracatın azalmasının da etkisi olmuştur. Ayrıca millileştirme politikası çerçevesinde devlet eliyle yapılan satın almalar döviz açı̆̆ını arttırmıştır. Özellikle yabancı şirketlerin imtiyazındaki demiryolu hatlarının millileştirilmesi ve yeni hatların yapılması maddi bir yük getirmiştir. Diğer yandan Osmanlı borçlarının taksitinin bu döneme denk gelmesi de önemli bir etken olmuştur (Köklü, 1947, s.32; Aysan, 1980, s.47-48).

Bunların haricinde üzerinde durulması gereken bir husus da 1929 yılında yeni ve korumacı gümrük tarifesinin yürürlüğe gireceğinin farkında olan ithalatçlların eski tarife üzerinden çok miktarda mal ithal etmeleridir. Yüksek kar elde etme fırsatını kaçırmak istemeyen İthalatçılar, yeni tarife yürürlüğe girmeden hemen önce çok miktarda mal ithal etmişlerdir. Bu ithal mal fazlası, dış ticaret açığının artmasına neden olmuş ve açık 1929 yılında iki katına çıkmıştır (Köklü, s.32; Aysan, s.47-48; Keyder, 1993, s.97). 
Bu dönemde devletin kambiyo işlerinde ödemeleri erteleyeceğinden korkan tacir ve bankerlerin Türk Lirasına karşı spekülasyon yapmaya başlamaları da 1929 Aralık ayında Türk parasının değerini Sterlin karşısında en düşük seviyeye getirmiştir (Keyder, s.115).

Türkiye, krizin oluşturduğu bu olumsuz tablodan korunmak için önemli adımlar atmıştır. Kriz dönemini kendi iç dinamikleri ile atlatabilecekleri düşünülen dönemin güçlü devletlerinde bile hükümetler sosyal ve ekonomik hayata müdahale etmek zorunda kalmışlardır. Bu bağlamda pek çok genişletici ve daraltıcı tedbirlerle milli ekonomilerini koruyarak krizle mücadele etmeye çalışmışlardır (Zarakoğlu, 1982, s.92). Atatürk'ün ekonomi politikası denk bütçe, diş ticaret dengesi ve devletin yatırım harcamalarının, elde edilen gelirlere denk olduğu bir sistem üzerine inşa edilmiştir. Bu denge ile hedeflenen ülkede enflasyonu engellemek ve devlet hazinesinin itibarını korumaktır. Atatürk içerde enflasyonun artması durumunda Türk Lirasının dışardaki değerinin de düşeceğini düşünerek tedbirlerini bu yönde almıştır (Aysan, s.99). Dünya ekonomik krizine karş1 da hükümet, Atatürk'ün denge politikasını sürdürmüştür. Türk parasının değer kaybını ve dış ticaret açığını önlemek üzere kısıtlayıcı tedbirler alarak sağlam bir dış ekonomi politikası uygulamak suretiyle önemli sonuçlar elde etmiştir (Aysan, s.60-61).

\section{Türk Parasını Korumak İçin Alınan Tedbirler}

Türk parasının yabancı paralar karşısında değer kaybını önlemek için 1929 yılının ortalarından itibaren korumacı politikalar çerçevesinde bir dizi tedbirler alınmaya başlanmıştır. Buna istinaden kambiyo krizini çözmek adına atılan ilk adım 16 Mayıs 1929 tarihinde 1447 sayılı Menkul Kıymetler ve Kambiyo Borsaları Kanunu'nun çıkarılması olmuştur (T.C. Resmi Gazete [TCRG], 30 Mayıs 1929, say1: 1203. Bu kanunla ihtiyaçları karşılamak için döviz bütçesi oluşturmak usulü kabul edilirken spekülasyona karşı esaslar da belirlenmiştir (Köklü, s. 36). Ayrıca kanunla menkul kıymetler ve kambiyo konusunda alınacak kararlar, atamalar ve borsaların nerede kurulacağ recektir. Böylece devlet, korumacılığını para politikası üzerinde göstermeye başlamıştır. 
Menkul Kıymetler ve Kambiyo Borsaları Kanunu'nun uygulanmasından sonra da kambiyo krizi devam etmiştir. Krizi sona erdirmek adına ülkeye giren, çıan ve mevcut dövize müdahale edebilmeyi sağlamak amacıyla Türk Parasının Kıymetini Koruma Hakkında Kanun çıkarılmıştır (Köklü, s.36). Böylece 20 Şubat 1930 tarih ve 1567 sayı ile çıkarılan bu kanunla her türlü mal, kıymetli evrak ve paranın ülkeye giriş çıkışında Türk parasının kıymetinin korunması yönünde alınacak kararlar devlete bırakılmıştır. Ayrıca kanuna, kurallara uymayan bireylere ve tüzel kişilere çeşitli ağır para cezaları verileceğine dair, maddeler eklenerek caydırıcı tedbirler alınmıştır (TCRG, 25 Şubat 1930, sayı: 1433). Başvekil İsmet Paşa da Mecliste yaptığı konuşmada Türk parasının değerini korumak için alamayacakları tedbir olmadığını söyleyerek hükümetin bu konuda ne kadar kararlı olduğunu göstermiştir (Milliyet, 21 Şubat 1930, s.1.). Zaten bundan sonra yapılacak tüm çalışmalar da paranın kıymetini korumak üzerine olacaktır.

Bu süreçte artık devletin kambiyo piyasasına tam anlamıyla hâkim olması gerektiği anlaşılmış ve bunun için bir ihraç bankası kurulması gerekliliği ortaya çıkmıştır. Bu ihraç bankası kuruluncaya kadar bahsi geçen bankanın bir takım vazifelerini yerine getirmek üzere 24 Mart 1930 tarihinde Bankalar Konsorsiyumu kurulmuştur. Bu konsorsiyumun görevi, merkez bankası kuruluncaya kadar kambiyo piyasasını düzene koymak ve Maliye Vekâletinin direktifleri doğrultusunda Türk parasının değerinin haddinden fazla dalgalanmasına engellemek olarak belirlenmiştir. Bankalar Konsorsiyumu, bu beklentilere cevap vererek görevini yerine getirmiş ve kuruluşundan sonra Türk Lirası, borsada esas döviz olarak kabul edilen İngiliz Sterlini karşında fazla değişiklik göstermemiştir (Köklü, s.39-40).

Nihayet 11 Haziran 1930 tarih ve 1715 sayılı kanun ile T.C. Merkez Bankası resmen kurulmuştur. Bankanın kurulmasıyla, hükümet ile ortak çalışmak suretiyle Türk Parasının kıymetini koruma görevi bankaya verilmiştir. Ayrıca; hazine muamelelerini ifa etme, para piyasasını kontrol etme ve para tedavülü görevleri de Merkez Bankasına bırakılmıştır (TCRG, 30 Haziran 1930, sayı: 1533; Cumhuriyet, 12 Haziran 1930, s.1-2). Banka ancak 3 Ekim 1931 tarihinde fiilen çalışmaya başlasa da piyasaya müdahale etmemiştir (Kocabaşoğlu vd, 2001, s.41). Bu süreçte mevcut olan konsorsiyum faaliyetlerini devam ettirmiş ancak Merkez Bankası bu 
görevleri 1932' den sonra devralmıştır (Tekeli ve İlkin, 1997, s.238). Merkez Bankasının açılması ve faaliyete başlaması ülkede para politikalarının kontrolünün sağlanacağ1 yönünde büyük beklentilere neden olmuştur (Nadi, 13 Haziran 1930, s.1; Siirt Mebusu Mahmut, 8 Ekim 1931, s.1). Neticede bu beklenti boşa çıkmamış ve Merkez Bankası çalışmaya başladıktan sonra Türkiye piyasasındaki yabancı bankaların etkisini azaltmıştır (Glasneck, 1976, s. 258). T.C. Merkez Bankasına verilen para basma yetkisinin ölçülü kullanılmasına rağmen, 1930'a kadar Sterlin karşısında düşme eğiliminde olan Türk Parasının değeri 1931'den itibaren sürekli artmıştır (Aysan, s.47).

\section{Bankacılık Sektörüne Müdahale}

Türk parasını koruma tedbirleri çerçevesinde yukarıda da belirttiğimiz gibi 1929 ekonomik krizi ile birlikte hükümet para piyasasını denetleme yöntemini tercih etmiş ve Merkez Bankasının kuruluşu ile sonuçlanan bir dizi tedbir almıştır (Keyder, s.115). Merkez Bankası ile para politikası bir düzene sokulsa da gerek devlet yatırımlarının gerekse özel teşebbüslerin kredi ve destek ihtiyacını karşılayabilecek bir sistemin de oluşturulması gerekiyordu. Osmanlı'nın son döneminde olduğu gibi 1923-1929 döneminde de kredi ihtiyaçları yabancı banka ve şirketler tarafından sağlanmıştı. 1930'larda başlatılan devlet destekli yatırım hamlesini, güvenilirliği belirsiz olan bu yabancı para kaynaklarına bırakmak çok sağlam bir tercih olarak görülmemiştir. Neticede bağımsız ve milli atılım hamlesinin her aşamasını net ve sağlam adımlarla atmak için kaynaklarının da bir o kadar milli olması gerekiyordu. Buna istinaden çıkarılan bir dizi kanun ve ortaya çıkarılan kuruluşlarla bankacılık sektörünü millileştirme çalışması başlatılmıştır.

Cumhuriyetin 1923-1929 döneminde kurulan; İş Bankası, Sanayi ve Maadin Bankası, Emlak ve Eytam Bankası ve Osmanlı'dan miras kalan Ziraat Bankası aracılığıyla bankacılık sektöründe önemli adımlar atılmış olsa da bu kurumlardan özellikle, sanayi sektöründe beklenen atılımı destekleyici bir verim alınamamıştır. Ekonomik buhrandan sonrası dönemde ilk iş olarak sanayicinin kredi ihtiyacını karşılamakta yetersiz kalan Sanayi ve Maadin Bankası 1932 yılında kapatılmış ve bu görevi ifa etmek üzere Türkiye Sanayi Kredi Bankası ve Devlet Sanayi Ofisi kurulmuştur 
(Vural, 2008, s.102). Ardından sanayi sektörünün en önemli destekçisi olacak olan 11 Temmuz 1933 tarih ve 2262 sayılı kanunla Sümerbank kurulmuştur. Böylece, banka devletin elindeki fabrikaları devralarak yönetecek ve özel teşebbüslerdeki devlet hisselerini kontrol edecektir. Ayrıca banka vasitasıyla yerli hammadde kaynakları ile yerli sanayi üretimine kredi desteği sağlanacaktır (TCRG, 11 Haziran 1933, sayı: 2424; Nizameddin Ali, 27 Haziran 1933, s.1). Aynı yıl belediyelerin amme hizmetlerini yerine getirmelerine destek olmak amaciyla 15 milyon lira sermaye ile 11 Haziran 1933 tarih ve 2301 sayılı kanunla Belediyeler Bankası kurulmuştur (TCRG, 24 Haziran 1933, sayı: 2435; Milliyet, 12 Haziran 1933, s.1-4). Ülkedeki yer altı ve üstü maden ve enerji kaynaklarının çıkarılması ve araştırılmasına destek olmak amaciyla 2 Haziran 1935 tarih ve 2805 sayılı kanunla Etibank kurulmuştur (TCRG, 22 Haziran 1935, sayı: 3035).

Bu dönemde kurulan bankaların yanı sıra çıkarılan çeşitli kanun ve kararnamelerle de piyasa kontrol altına alınmaya çalışılmıştır. Ekonomi krizden sonraki süreçte resmi kaynaklardan kredi ve destek göremeyen tüccar ve esnaf tefecilerden yüksek faizli borç almak zorunda kalmıştır. Borçlarını ödeyemeyen tüccar ve esnaf arasında iflaslar artmıştır. Küçük yatırımcıyı tefecilerden korumak ve destek olmak üzere 8 Haziran 1933 tarih ve 2279 sayılı Ödünç Para Verme İşleri Kanunu çıkarılmıştır. Kanunla birlikte ödünç para vermek işleri bir düzene sokulmuştur. Kanuna göre; faizden para kazanmak isteyenler artık hükümetten izin almak zorunda olacaklardır. Faiz oranları ve süreleri de kanunla belirlenecektir. Ayrıca kanuna uymayanlara ağır para ve hapis cezaları uygulanacaktır. Ödünç Para Verme İşleri Kanunu ile aynı tarihte 2284 sayılı Halk Bankası ve Halk Sandıkları Kanunu çıkarılarak ülkenin her yerindeki küçük esnafın ve vatandaşın düşük miktarlı kredi ihtiyaçlarını karşılanması için adım atılmıştır (TCRG, 18 Haziran 1933, sayı: 2430; Fındıkoğlu, 1967, s.247-248; Milliyet, 30 Mayıs 1933, s.1-6; Milliyet, 9 Haziran 1933, s. 1-6; Vakit, 9 Haziran 1933, s.1-10).

Sonuç olarak ekonomik kriz ile mücadele için alınan tedbirler neticesinde 1929 'da 34 olan yabancı banka sayısı 1933'te 10'a düşmüş ve aynı dönemde beş tane milli banka kurularak faaliyete başlamıştır (Kazgan, 2004, s.65). 


\section{Vergiler Üzerinden Alınan Tedbirler}

Dünya ekonomik krizi ile mücadelede etmek üzere alınan mali tedbirlerin önemli bir ayağını da vergiler oluşturmuştur. Gerek var olan vergilerde çeşitli düzenlemeler yapmak gerekse yeni vergiler çıkarmak suretiyle krizle mücadele edilmiştir. Elbette vergilendirme yapılırken krizden etkilenen halkın durumu göz ardı edilmemiştir.

Arazi Vergisi, Hayvanlar Vergisi, Bina Vergisi, Kazanç Vergisi, Veraset İntikal Vergisi ve Muamele Vergisi değiştirilerek kriz dönemine uygun hale getirilen vergiler olmuştur. İktisadi Buhran Vergisi, Muvazene Vergisi, Hava Kuvvetlerine Yardım Vergisi ve Dâhili İstihlak Vergisi ise kriz döneminde ilk kez uygulanan vergiler olmuştur.

Arazi Vergisi, Bina Vergisi, Hayvanlar Vergisi, Veraset İntikal Vergisi ve Muamele Vergisi 1931 yılında çeşitli kanunlarla değiştirilerek krize uygun hale getirilmişlerdir. Bina Vergisinde yapılan değişiklikle mükelleflere bazı kolaylıklar getirilmiştir. Bina ve arazi ayrımı daha dikkatli şekilde yapılarak karışıklığın önüne geçilmiştir. Tarımla uğraşanların binaları ve tarımsal üretimde kullanılan binalar ile devlete, mahalli idarelere ve kamu yararına olan binalar vergiden muaf tutulmuştur. Ayrıca yeni binalar üç yıl süre ile vergiden muaf tutulurken genel anlamda da tüm binalar için vergi oranı \%12'ye düşürülmüştür. Böylece eskiden 170 lira vergi veren bina sahibi 96 lira vergi ödeyecektir. (Milliyet, 11 Haziran 1931, s.1; Milliyet, 29 Temmuz 1931, s.3; Tekeli ve İlkin, 1982, s.266). Hayvanlar Vergisinde yapılan değişikle, hayvan başına alınan vergi oranı \%20 oranında azaltılırken vergi kaçakçılığından alınan cezada düşürülmüştür. İlerleyen yıllarda hayvan fiyatlarının düşmesi ve bu fiyatlara göre vergi yükünün ağır gelmesi üzerinde 1936 yılında önemli derecede vergi indirimi yapılmıştır (Tekeli ve İlkin, 1982, s.265; Saraçoğlu, 2009, s.135). Veraset İntikal Vergisinde yapılan değişiklikle bu verginin Medeni Kanuna uygun hale gelmesi sağlanmıştır. Muamele Vergisi de 21 Temmuz 1931 tarihinde 1860 sayılı kanunla değiştirilmiştir (TCRG, 2 Ağustos 1931, sayı: 1862). Yapılan değişiklikle vergilendirme sanayici lehine kolaylık sağlayacak bir duruma getirilse de 1934 yılında devletin ihtiyaçlarının arttığı süreçte sanayi kesiminden alınan vergi oranının arttırılmasına karar verilmiştir (Tekeli ve İlkin, 1982, s.267-273). 
Kazanç Vergisi ise vasıtasız vergiler arasında en önemlisidir. 27 Kasım 1926 tarih ve 775 sayılı Kazanç vergisi kanunu 1927 yılında değiştirilmesine rağmen bu kanun hakkında şikâyetler bitmemiştir. TBMM'de uzun müzakerelerden sonra 22 Mart 1934 tarih ve 2395 sayılı yeni Kazanç Vergisi Kanunu kabul edilmiştir. Yeni kanuna göre; sanat ve ticaret icrasından doğan tüm kazançlar menkul kıymetlerden elde edilen kazançlar, ticari olmayan mesleklerden elde edilen gelirler, maaş ve ücret benzeri emeğe dayalı kazançlar vergilendirileceklerdir (TCRG, 25 Mart 1934, sayı: 2662; Tekeli ve İlkin, 1982, s.266). Eğlence mekânlarından alınan vergiler attırılmıştır. Ayrıca beyannamelerin tanzim ve kontrolü yeni hükümlere bağlanarak tahakkuk memurlarının yetkileri sınırlandırılmıştır. Bu kararla memurların görevlerini kötüye kullanmasının ya da zafiyet göstermelerinin önüne geçileceği gibi hazinenin zarar etmesi de engellenecektir (Sadrettin, 16 Mart 1934, s.1). Yeni kazanç vergisi görüşülürken doktor, dişçi ve avukatlar başta olmak üzere serbest meslek gruplarının yükünün fazla olduğu hususunda yapılan itirazlar dikkate alınarak serbest meslek sahiplerine uygulanan kazanç vergisi oranı düşürülmüştür (Akşam, 20 Mart 1934, s.2; Milliyet, 21 Mart 1934, s.1-7). Serbest meslek sahiplerinden alınacak kazanç vergisinin düşürülmesine rağmen şikâyetler devam etmiştir (Haber, 15 Nisan 1934, s.1-7; Haber, 10 Ekim 1934, s.1). Bu nedenle itirazları değerlendirmek üzere her maliye tahakkuk bölgesinde bir komisyon kurulmasına karar verilmiştir. Bu sayede şikâyetlerin kısa sürede giderilmesi ve kazanç vergilerinin ödenmesinde bir gecikme olmaması planlanmıştır (Akşam, 11 Ekim 1934, s.3).

Ekonomik krizden sonra alınmaya başlanan vergilerden ilki 12 Haziran 1930 tarihinde kabul edilen 1718 sayılı kanunla şeker, glikoz, ham petrol ve müştaklarından alınmaya başlayan Dâhili İstihlak Vergisidir. 1934 yılına kadar çıkarılan çeşitli kanunlarla Elektrik, Havagazı, kakao, kakaoyağı, çay, kahve, kauçuk, lastik boru, pencere camı, kâğıt ve mukavva, deri ürünleri, pamuk ipi, pamuklu mensucat, yün ve yünlü ürünler, bakır ve alaşımı da istiklal vergisi kapsamına alınmıştır. Ayrıca bir ürüne özgü çıkarılan vergi olarak 29 Mayıs 1934 tarih ve 2466 sayılı Buğdayı Koruma Vergisi çıkarılmıştır (Tekeli ve İlkin, 1982, s.273-276). Ekmek üzerinden alınmaya başlanan bu vergi ile hedeflenen, buğdayı dolayısıyla ülke ekonomisinin temel taşı olan çiftçiyi koruma altına almak olmuştur. Bu sayede buğday fiyatları kontrol edilebilecek ve hem üretici hem de tüketici 
mağdur edilmemiş olacaktır (Sadrettin, 12 Mart 1934, s.1; Şükrü, 30 Mayıs 1934, s.1).

Kriz dönemine özel çıkarılan vergilerden olan İktisadi Buhran Vergisi ise 30 Kasım 1931 tarih ve 1890 sayılı kanun ile alınmaya başlanmıştır. Bu vergi krizin yükünü giderme konusunda yetersiz kalınca 29 Mayıs 1932 tarih ve 1996 sayılı kanunla bina vergilerine de uygulanmaya başlanmıştır. Böylece bina vergisinden muaf olanlar bile buhran vergisi ile eklenen vergiyi ödemekle sorumlu olmuşlardır (Tekeli ve İlkin, 1982, s.267-268). Verginin ne ölçüde ve hangi binalardan alınacağı hususunda karışıklıklar yaşanması nedeniyle buhran vergisi bina vergisi mükelleflerinin tamamına Ekim ayında yansıtılmıştır (Akşam, 20 Eylül 1932, s.3). 1932 yılının Haziran ayında Serbest meslek erbabından da buhran vergisi alınması gündeme gelmiş ve gerekli çalışmalar başlatılmıştır (Akşam, 29 Haziran 1932, s.1; Cumhuriyet, 29 Haziran 1932, s.1). Ancak bütçe encümeni başkanı Hasan Fehmi Bey, serbest meslek erbabından kazanç vergisi dâhilinde gerekli gelir vergilerinin alınmasından dolayı ayrıca bir buhran vergisi almak gibi bir düşünceleri olmadığını açıklamıştır (Vakit, 15 Şubat 1933, s.2). Neticede İktisadi Buhran Vergisi, geniş uygulama alanı ile kriz döneminin önemli vergilerinden biri olmuştur.

Kriz döneminin bir diğer vergisi ise 1 Haziran 1932 tarihinden itibaren sadece bir kez alınmak üzere çıkarılan Muvazene Vergisi olmuştur. Maaşlı çalışanlara yönelik çıkarılan vergiye göre; çalışanlar ücretlerinden kazanç ve İktisadi buhran vergisi düşürüldükten sonra kalan miktar üzerinden \%10 daha vergi vermekle yükümlü olacaklardır. Sadece bir yıl için çıkarılmış olsa da 1933 ve 1934 yıllarında da çalışanlardan Muvazene Vergisi alınmıştır. Bu süreçte Muvazene Vergisinden elde edilen gelir, sadece maaş gelirinden alınmasına rağmen, İktisadi Buhran Vergisinden daha fazla olmuştur (Tekeli ve İlkin, 1982, s.266-269; Saraçoğlu, s.137). Hava Kuvvetlerine Yardım Vergisi de bu dönemde ilk kez alınan vergilerden olmuştur. Hava Kuvvetlerini kalkındırmak amacıyla 25 Aralık 1935 tarih ve 2882 sayılı kanuna ile alınmaya başlayan vergiye göre çeşitli kazanç ve ikramiyeler üzerinden $\% 2$ oranında kesinti yapılacaktır. Serbest işçiler ile zirai işçiler ise bu vergiden muaf tutulmuşlardır (TCRG, 2 Ocak 1936, sayı: 3195). 


\section{Dış Ticaret Dengesi}

Dünya ekonomik krizinden sonraki süreçte devlet müdahaleci politikalara yönelmek zorunda kalmış ve 17 Mayıs 1931'de Üçüncü CHP Kurultayında devletçilik ilkesi benimsenmiştir. Bu yeni ekonomi modeli çerçevesinde yeni gümrük tarifesi ve bu tarifeye paralel çıkarılan kanunlar ile yeni bir ticaret anlayışı da oluşmuştur. Hükümet korumacı politikalarını hayata geçirebilmek adına diş ticaret alanında da bir dizi yeni karar alacak ve bu kararlar çerçevesinde dış dünya ile ilişkiler yeni anlaşmalara göre dizayn edilmeye çalışılacaktır.

Kriz döneminde alınan tedbirlerden önce genel olarak Atatürk dönemine bakacak olursak, daha önce de ifade ettiğimiz üzere, denk bütçe ve ödeme dengesinin sağlanması üzerine kurulmuş bir ekonomi politikası olduğunu görmekteyiz. Atatürk'e göre, ödeme dengesinin en önemli yolu dış ticaret dengesinin sağlanmasıdır. Bu nedenle ithalat yapılan ülkelere ihracat yapmak önemli bir gerekliliktir (Aysan, s.100). Ancak Türkiye' nin 1923-1929 döneminde sürekli olarak ithalat ihracattan fazla olmuş ve bu fazlalığın bir kısmı yabancı sermaye ile finanse edilmiştir. Böylece, tüm çabaya rağmen, bu süreçte bir diş ticaret açığı oluşmuştur (Keyder, s.102). Ayrıca 1929 yılında yaşanan ekonomik krizin dünyayı etkisi altına almasıyla tarım ürünleri fiyatlarının aşırı oranda düşmesi Türkiye'nin dış ticaret dengesinin daha da bozulmasına neden olmuştur. Bu da hükümeti dış ticareti yeni kanunlarla kontrol altına almaya yöneltmiştir (Yerasimos, s.415).

Bu bağlamda kriz döneminde hükümetin dış ticaret alanında koruyucu tedbirler alması hususunda elini güçlendiren en önemli gelişme 1 Haziran 1929 tarihinde 1499 sayılı yeni Gümrük Tarifesi Kanununun yürürlüğe girmesi olmuştur (TCRG, 1 Temmuz 1929, sayı: 1230). Böylece Türkiye, Lozan Antlaşmasına göre beş yıl daha devam etmesini kabul ettiği 1916 gümrük tarifesinin bağlayıcılığından kurtulmuş ve yeni gümrük tarifesi belirleme hakkını elde etmiştir. Yeni tarifenin belirlenmesi sürecinde tüccarlar ve sanayiciler kendi çıkarları doğrultusunda bir tarife çıması hususunda hükümeti etkilemeye çalışarak kulis faaliyetlerinde bulunmuşlar ve çeşitli taslaklar hazırlanmışlardır (Keyder, s.94). Neticede ise eski tarifeden ve İstanbul burjuvazisinin istediğinden daha korumacı bir 
gümrük tarifesi ortaya çıkmıştır (Boratav, 1987, s.36). Keyder'e göre; yeni tarife, tüccar ve sanayicilerin arasındaki güç dengesini yansıttı̆̆ı gibi ekonomik krizin etkilerini de taşımaktaydı. Ayrıca düşünüldüğü gibi himayecilikten öte 1930'ların korumacı politikalarına geçişin, tekelci bir dış ticaret anlayışının etkisiyle oluşturulmuştu (Keyder, s.95). Her ne olursa olsun bir gerçek vardı ki o da yeni tarifenin hükümetin eskisinden daha etkili, sert ve radikal kararlar almasına olanak sağlayacağıydı. Bu kararlar devletin müdahaleci politikaları çerçevesinde sadece ticarete değil tüm sektörlere yön verecek etkide olacaktır.

Yeni gümrük tarifesinin kabul edilmesinden sonra gümrük ve inhisar işlerini daha etkin yürütmek ve kontrol etmek adına bir dizi kanun çıarılmış ve yeni kurumlar oluşturulmuştur. Bunlardan ilki gümrük ve inhisar işlerini takip etmek üzere 29 Aralık 1931 tarih ve 1909 sayılı kanunla kurulan Gümrük ve İnhisarlar Vekâleti olmuştur (TCRG, 30 Aralık 1930, sayı: 1989). Devletin ve tüccarın gelir kaybının önüne geçmek üzere önemli adımlar atılmış öncelikle 19 Temmuz 1931 tarihinde çıkarılan 1841 sayılı Gümrük Muhafaza Memurlarının Askerî Teşkilâta Göre Tensiki Hakkında Kanun ile gümrük muhafaza memurları askeri düzene sokulmuş (TCRG, 27 Temmuz 1931, sayı: 1858) 7 Ocak 1932 tarihinde 1917 sayılı kanunla sinır ve gümrüklerin güvenliğini daha verimli korumak amacıyla Gümrük Muhafaza Umum Kumandanlığ1 kurulmuştur (TCRG, 12 Ocak 1932a, sayı: 2000). Kumandanlığın teşkil edildiği gün kaçakçlık yapanlara çok ağır cezai yaptırımlar içeren 1918 sayılı Kaçakçılığın Men ve Takibine Dair Kanun çıkarılarak sınır ve gümrük güvenliği için önemli bir karar daha alınmıştır (TCRG, 12 Ocak 1932b, sayı: 2000).

Kriz döneminde hükümetin diş ticaret dengesini kurmak için kullandığı önemli politikalardan biri de vatandaşı yerli malları kullandırmaya ve tasarrufa özendirmek olmuştur. Yerli malı kullanımını arttırmak ve tasarrufu önleme faaliyetlerini geniş kitlelere yaymak amacıyla 12 Aralık 1929 tarihinde Milli İktisat ve Tasarruf Cemiyeti kurulmuştur. Cemiyetin başarılı olması durumunda ithalat azalacak ve buna bağlı olarak dış ticaret açığı kapanacaktır. Buna bağlı olarak Türk parasının dışa çıkışı önlenerek hükümet milli ekonomi politikasına uygun yatırımları yapabilecektir. Hükümetin bu kadar önemli bir görev verdiği cemiyet kısa sürede teşkilatlanarak halkı ithal mallarına olan ilgisinden vazgeçirmeye ve tasarrufa yönlendirmeye başlamıştır (Semiz, 1996, s.49-63). 
Hükümet kriz döneminde ikili ilişkilerinde, dış ticaret dengesini sağlamak için, basit bir şekilde ihraç ettiğin kadar ithal et anlayışı ile hareket etmiştir. Ticari ilişkiler olan ülkelerle, imkânlar dâhilinde karşılıklı ve eşit miktarlı alışveriş yapmayı sağlayacak anlaşmalar yapılmıştır. Böylece kriz döneminin dış ticaret politikasını çeşitli kontenjan, takas ve kliring anlaşmaları oluşturmuştur denebilir. Bu bağlamda hükümet, öncelikle 10 Mart 1930 tarihinde 1705 sayılı Ticarette Tağşişin Men'i ve İhracatın Murakabesi ve Korunması Hakkında Kanunu çıkararak dâhili ve harici ticari menfaatleri korumak üzere ilk adımı atmıştır. Bu kanunla ithal edilecek malların kalite kontrolünü sağlamak suretiyle ülkeye hileli ürün sokulmaması için tedbir alınmıştır (TCRG, 19 Haziran 1930, sayı: 1524). İthal edilen malın kalitesi hususunda çıarılan bu kanundan bir müddet sonra 27 Temmuz 1931 tarih ve 1873 sayılı Ticaret Mukavelesi ve Modus Vivendi Akdetmeyen Devletler Ülkesinden Türkiye'ye Yapılacak İthalata Memnuiyetler veya Tahdit veyahut Takyitler Tatbikine Dair Kanunu çıkarmıştır (TCRG, 1 Ağustos 1931, sayı: 1861). Bu kanunla hükümet, daha önce Türkiye ile ticaret anlaşması yapmamış ve yeni bir anlaşma yapmaktan kaçınan ülkelere ithalatı men etme ya da sınırlarını belirleme yetkisini üzerine almış ve böylece ülke ekonomisini koruma adına önemli bir adım atılmıştır. Bu kanunun çıkarılmasında 1931 yılında özellikle Sovyetler Birliği ve Japonya gibi ülkelerin uyguladığı dampinglerin (aşırı fiyat düşürme) yerli üreticiyi zor durumda bırakması da etkili olmuştur (Tekeli ve İlkin, 1982, s.222). Bu anlaşma ile ucuz ithal mal karşısında ezilen ve mücadele gücü olmayan yerli üretici koruma altına alınmıştır.

Kriz döneminin önemli uygulamalarından biri de kontenjan usulü olmuştur. Hükümet, 12 Kasım 1931 tarih ve 11940 sayılı kararname ile ülkeye sokulabilecek azami ithal mal miktarını belirleyerek liste yayınlamıştır. Liste her ay yenilenecek ve kontenjanların belirlenmesinde yerli üretim ve sanayi sektörünün ihtiyaçları göz önünde bulundurulacaktır. Ayrıca kontenjanlar nedeniyle, ülkede pahalılığa neden olabilecek ve kişisel tekel oluşturabilecek teşebbüslere engel olmak üzere tedbirler alınacaktır (TCRG, 16 Kasım 1931, sayı: 1951). İlerleyen süreçte hükümet çıkardığı çeşitli kararnamelerle kontenjan usulünde yeni düzenlemeler yapmıştır. 22 Mart 1932 tarihinde kararname yayınlanmadan önce sipariş edilen ve bedeli döviz olarak ödenmiş malların ülkeye girişine izin verilerek daha önceden sipariş vermiş olan tüccarın mağduriyeti giderilmiştir. 2 Haziran 
1932 tarihinde çıkarılan kararname ile ise Teşviki Sanayi Kanunundan faydalanan fabrikalara kontenjan usulü ile kolaylık sağlanmıştır. 1933 yılı şubat ayında çıkarılan 13887 ve 13888 sayılı kararnameler ile de tüm kontenjan mevzuatı bir araya getirilmiş ve kontenjanlar altı aylık olarak hazırlanmaya başlanmıştır (Tekeli ve İlkin, 1982, s.228-237).

Kontenjan usulü ile kota uygulaması getirilen dış ticaret 1932 yılında ilki Fransa ile olmak üzere çeşitli ülkelerle yapılan ikili kliring anlaşmaları düzenlenmeye başlanmıştır (Kazgan, s.65). Yani Türkiye malını alan ülkeden mal alarak ve anlaşma yapılan ülkelere ithalat önceliği tanıyarak ihracatını güçlendirmeye çalışmıştır. Hükümetin kliring politikası çerçevesinde 29 Mayıs 1932 tarihinde 1993 sayılı Takas Komisyonu Teşkili Hakkında Kanun çıkarılarak İktisat Vekâletine bağlı bir takas komisyonu oluşturulmuştur. Bundan sonra ithalat yapmak isteyen tüm kurum, kuruluş ve şirketler teklif ve taleplerini bu komisyona bildireceklerdir. Komisyon teklif ve talepleri değerlendirirken nasıl bir takas uygulanacağına da karar verecektir. Ancak hususi ticaret mecburi takasa tabi tutulmamıştır (TCRG, 31 Mayıs 1932, sayı: 2112). Bu anlaşmalar vasıtasıyla dış ticaret dengesinde ihracat lehine önemli bir artış yaşanmıştır. Kliring ve takas usulünün devam ettiği süreçte 5 Temmuz 1937 tarihinde çıkarılan 2/7005 sayılı Genel İthalat Rejimi Kararı ile dış ticaret ilişkilerinde bir serbestlik sağlanmıştır (TCRG, 13 Temmuz 1937, sayı: 3655). Ancak bu karar kliring anlaşmaları ile sağlanan diş ticaret dengesinin bozulmasına neden olmuş ve 1938 y1lında diş ticaret açığı verilmiştir. Bunun üzerine serbestlik getiren uygulamalardan vazgeçilerek yeniden sinırlamalar getirilmiştir (Kepenek ve Yentürk, 1994, s.70).

Kriz sonrası ihracatı geliştirmeye yardımcı olması nedeniyle üzerinde durulması gereken kurumlardan biri de 1931 yılında Türkiye İş Bankası bünyesinde kurulan İş Limited Şirketi olmuştur. Bu şirket vasıtasıyla harici ticaret fiyatlandırmalarına belli bir standart getirilerek üreticinin malını en iyi şartlarda satmasına yardımcı olmaya çalışılmıştır ("Dünya Buhranı ve Türkiye", 1932, s.4; Nadi, 1932, s.1).

Neticede kriz döneminde alınan tedbirler vasıtasıyla Türkiye dış ticaret açığını kapatmıştır. Hatta 1930 yılından itibaren dış ticaretin fazla vermesiyle birlikte Osmanlı' dan kalan borçlar ödenebilir hale gelmiştir (Kazgan, s.65). 


\section{Kriz Karşısında Alınan Tedbirlerin Türk Ekonomisine Etkisi}

Türkiye, krizle mücadelede iktisadi kalkınma modelini benimsemiştir. Bunu sağlamak için de tarıma dayalı ekonomiyi çeşitlendirmek üzere sanayileşme hamlesi başlatılmış, haberleşme ve taşımacılık alanında yapılan yeniliklerle bölgesel piyasaların bağı kuvvetlendirilmiştir. Devlet yatırımlarını ve özel teşebbüsü destekleyici önlemler alınmış, sanayi, madencilik, bankacılık ve enerji sektörlerinde yapılan yatırımlarla arzu edilen kalkınma gerçekleştirilmeye çalışılmıştır. Bu kalkınma hamlesi gerçekleştirilirken Türk parasının değerini korumak, yeni gümrük tarifesi çerçevesinde gümrük vergilerini arttırmak ve diş ticareti koruyucu tedbirler almak suretiyle dış ödeme dengesi de sağlanmıştır (Zarakolu, s.103).

Bu çerçevede krizle mücadelede Türk parasını korumak adına bir dizi önlem alınmıştır. İngiliz Sterlini Türk Lirası karşısında 1919 yılında 374 kuruşken 1923'te yaklaşık iki kat artarak 762.94 kuruşa yükselmiştir. Bu artış sürekli devam etmiş ve 1929 yılı sonunda 1044.41 kuruşa yükselmiştir. Sterlinin TL karşısında 1929 yılı ortalaması ise 1008 kuruş olmuştur. Hükümetin ekonomik kriz karşısında aldığı mali tedbirler kısa sürede etkisini göstermiş ve Sterlin 1930 yılında az bir miktar gerileyerek 1034.07 kuruş olmuştur. Tedbirler asıl etkisini 1932 yılında göstermiş Sterlin 755.92 kuruşa kadar düşmüştür. Sterlin 1938 yılına kadar sürekli değer kaybederek 631.18 kuruşa kadar gerilemiştir. Krizden sonraki süreçte Türk parasının değeri, Sterlinde olduğu gibi, diğer yabancı paralar karşısinda da sürekli yükselmiştir. Amerikan Doları, 1929 yılında 206.87 kuruşken 1933 yılında hızlı değer kaybederek 171.42 kuruş olmuş ve 1938 y1lında 126.11 kuruşa kadar gerilemiştir. 1929 yılında 814 kuruş olan Fransız Frang1 ise 1938 yılında 360 kuruşa kadar gerilemiştir (İstatistik Umum Müdürlüğü [İUM], 1941, s.6-12). Rakamlardan da anlaşılacağı üzere Dünya ekonomik krizinden sonra hükümetin aldığı tedbirler sayesinde Türk Lirası yabancı paralar karşısında değer kazanmaya başlamıştır. 1938 yılına gelindiğinde yabancı para değerlerinde TL karşısında 1929 yılına oranla yarı yarıya bir düşüş olduğu görülmektedir.

Hükümetin bankacılık alanında aldığı tedbirler milli bankacılık için olumlu sonuç vermiştir. Türk bankalarında 1933 yılında yaklaşık 145 milyon lira mevduat bulunurken bu miktar her sene artış göstererek 1938 y1- 
lında yaklaşık 271 milyon liraya yükselmiştir. Böylece Türk bankalarındaki mevduat miktarı 5 yıl içinde $\% 87$ oranında artmıştır. Bu süreçte mevduat miktarı ile orantılı olarak mudi sayısında da \%68 oranında artış olmuştur. Türk bankalarına para yatıran mudi sayısı 1933'te 163.384 kişiden 1938 'de 274.075 kişiye çıkmıştır. Aynı dönemde yabancı bankalara baktığımızda ise 1933 yılında yaklaşık 46 milyon lira olan mevduat 1934'te \%16 oranında 1935'te ise \%8 oranında azalarak 35 milyon lira civarına düşmüştür. Yabancı bankaların mevduat miktarı 1938 yılına kadar bir miktar yükselse de Türk bankalarına oranla çok düşük kalmış ve ancak \%39 oranında yükselebilmiştir. Mudi sayısı da 1933'te 12.624 iken 1934 yılında \%12'lik bir düşüş yaşamıştır. Ancak ilerleyen yıllarda hızlı bir atış göstermiş ve 1938 yılında \%89 oranında yükselerek 23.803 kişiye çıkmıştır (IUUM, 1939, s.4-5). Ancak bu artışa rağmen yabancı bankalardaki mudi sayısı Türk bankalarındakinin sadece \%10'u kadar bir sayıya ulaşabilmiştir. Neticede Türk bankacılı̆̆ 1 kriz döneminde önemli bir atılım yaparak sektördeki yabancı sermaye hegemonyasının önemli ölçüde önüne geçilmiştir.

Kriz döneminde üzerinde durulan alanlardan biri de vergi sistemi olmuştur. Yukarıda da ifade ettiğimiz üzere yeni vergiler çıkarmak ve bazı vergileri yeniden düzenlemek suretiyle krize karşı tedbir alınmıştır. Krize karşı ilk kez çıkarılan vergileri incelediğimizde 1932-1933 döneminde en çok tahakkuk eden verginin 13.986 milyon lira ile Muvazene Vergisi olduğunu görüyoruz. Bu miktar sürekli artış göstererek 1937-1938 döneminde 21.590 milyona çıkmış ancak 1938-1939 döneminde 18.829 milyon liraya düşmüştür. İktisadi Buhran Vergisi, 1932-1933 döneminde tahakkuk eden 10.805 milyon lira ile Muvazene Vergisinin gerisinde kalsa da 1938-1939 döneminde kadar sürekli artış göstererek Muvazene Vergisini geçmiş ve 20.117 milyon lira olmuştur. İstihlak Vergisi ise 1932-1933 yılında 4.056 milyon lira tahakkuk etse de ilerleyen yıllarda büyük oranda artış olmuş ve 1938-1939 döneminde 18.829 milyon liraya yükselmiştir. Yeni çıkarılan vergilerden Hava Kuvvetlerine Yardım Vergisi de ilk alınmaya başlandığ 1 1935-1936 döneminde 1.719 milyon lira tahakkuk ederken 1938-1939 döneminde 6.287 milyon liraya yükselmiştir. Bu vergiler büyük oranda tahsil edilebilmiştir.

Kriz döneminde yeniden düzenlenen vergilere baktığımızda Gümrük Vergisinin ön plana çıtığını görürüz. Gümrük Vergisi, kriz döneminde alınan tüm vergiler içinde en çok gelir getiren vergi olmuştur. Gümrük 
Vergisi için 1932-1933 döneminde tahakkuk eden miktar 38.514 milyon lira olurken sonraki iki yıl bir miktar düşüş olsa da daha sonra sürekli artış yaşanmış ve 1938-1939 döneminde 49.326 milyon liraya yükselmiştir. Kriz döneminde yeniden düzenlenen vergileri, tahakkuk eden miktara göre, incelediğimizde Gümrük Vergisini sırasıyla Arazi, Kazanç, Bina ve Hayvanlar vergileri izlemektedir.

Tahsil edilme miktarına göre vergileri incelediğimizde ise tahsilat noktasında büyük bir sorun olduğu görülmektedir. Gümrük Vergisi hem en çok tahakkuk eden hem de \%100 tahsis edilme oranıla dönemin en çok gelir getiren vergisi olmuştur. İlk kez çıkarılan vergiler de büyük oranda tahsil edilerek önemli gelir getirmişlerdir. Ancak diğer vergiler için bunu söylemek mümkün değildir. 1932-1938 döneminde Kazanç ve Hayvanlar Vergilerinin neredeyse yarısı tahsil edilebilmiştir. Bu oran Arazi ve Bina Vergilerinde daha da düşerek \%20 oranında tahsilat yapılabilmiştir (IUM, 1940, s.70-248). Kriz döneminde alınan bu vergiler gerek krizle mücadelede gerekse devlet yatırımlarında kullanılan önemli gelir kalemleri olmuştur.

Kriz döneminde diş ticaret verilerini tablo1'de incelediğimizde ihracat miktarının 1930-1938 döneminde yaklaşık \%80 oranında arttığı görülmektedir. Aynı dönemde ithalat miktarı ise ancak \%36 oranında büyüyebilmiştir. Aslında 1938 yılı verisini dikkate almazsak büyümenin aksine bir daralma olduğunu ve ithalatın ihracatla ters orantılı olarak düştüğünü görmekteyiz. Ancak 1937 yılında Genel İthalat Rejimi Kararı ile dış ticarete getirilen serbestlik nedeniyle 1938 yılında ithalatta bir miktar artış yaşanmiştır.

Tablo 1. Türkiye'nin İhracat İthalat Miktarn 1930-1938 (Kaynak: Kaya, 1940, s.10-11)

\begin{tabular}{lllll}
\hline Yll & İhracat Miktar (Kilo) & Değişim \% & İthalat Miktar (Kilo) & Değişim \% \\
\hline 1930 & 813.277 .970 & 100 & 619.507 .876 & 100 \\
1931 & 920.499 .353 & 113.2 & 498.994 .629 & 80.5 \\
1932 & 1.113 .368 .194 & 120.9 & 417.909 .222 & 83.7 \\
1933 & 1.292 .579 .713 & 116.1 & 397.029 .414 & 95 \\
1934 & 1.686 .678 .850 & 130.5 & 477.237 .330 & 120.2 \\
1935 & 1.518 .754 .929 & 90 & 528.932 .242 & 110.8 \\
1936 & 1.406 .932 .852 & 92.6 & 538.144 .211 & 101.7 \\
1937 & 1.382 .340 .701 & 98.2 & 614.499 .529 & 114.2 \\
1938 & 1.464 .323 .084 & 105.9 & 845.054 .105 & 137.5 \\
\hline
\end{tabular}


Kriz döneminde para karşılığı olarak ithalat ihracat verilerini incelediğimizde ise artan ihracat miktarına oranla elde edilen gelir oranının aynı olmadığını görmekteyiz. Tablo2'de de görüleceği üzere 1928'den 1934'e kadar sürekli bir düşüş yaşanmıştır. Tabi bu düşüşün temel sebebi kriz nedeniyle Türkiye'nin ihracatının büyük bölümünü oluşturan tarımsal üretim fiyatlarının aşırı derecede düşmesidir. Ancak piyasaların toparlanmaya başlamasiyla 1934'ten sonra 1939'a kadar bir yükselme olmuştur. Aynı verileri ithalat üzerinde de görmek mümkündür. Hatta ithalatın giderinin daha sert oranda düştüğünü söyleyebiliriz. Krizin dünya piyasasını tamamen etkisi altına aldığı 1930 yılına baktığımızda ihracat geliri \%4.6 ithalat gideri ise \%43.7 azalmıştır. Böyle bir farkın oluşmasında krizin ithalat yapılan büyük ülkeleri daha fazla etkilemesinin yanı sıra Türkiye'nin dış ticaret açığını kontrol altına almak için aldığı tedbirler de etkili olmuştur.

Tablo 2. Türkiye'nin İhracat İthalat Verileri 1928-1939 (Kaynak: Türkiye İstatistik Китити [TUіK], 2009, s.475.)

\begin{tabular}{lllll}
\hline Yll & İhracat (Bin \$) & Değişim \% & İthalat (Bin \$) & Değişim \% \\
\hline 1928 & 88.278 & 9.3 & 113.710 & 5.5 \\
1929 & 74.827 & -15.2 & 123.558 & 8.7 \\
1930 & 71.380 & -4.6 & 69.540 & -43.7 \\
1931 & 60.226 & -15.6 & 59.935 & -13.8 \\
1932 & 47.972 & -20.3 & 40.718 & -32.1 \\
1933 & 58.065 & 21 & 45.091 & 10.7 \\
1934 & 73.007 & 25.7 & 68.761 & 52.5 \\
1935 & 76.232 & 4.4 & 70.635 & 2.7 \\
1936 & 93.670 & 22.9 & 73.619 & 4.2 \\
1937 & 109.225 & 16.6 & 90.540 & 23 \\
1938 & 115.019 & 5.3 & 118.899 & 31.3 \\
1939 & 99.647 & -13.4 & 92.498 & -22.2 \\
\hline
\end{tabular}

Türkiye, kriz döneminde aldığı tedbirler neticesinde dış ticaret dengesini korumuş, hatta önemli ölçüde ihracat lehine artış sağlamıştır. Tablo3'ü incelediğimizde 1930'dan itibaren ihracatın ithalata göre fazla verdiğini görüyoruz. Özellikle kontenjan, takas, kliring anlaşmaları ve çeşitli kanunlarla tedbirler alınan 1932 yılından itibaren dış ticaret dengesinde ihracat lehine önemli artış yaşanmıştır. Bu süreçte 1936 yılında dış ticaret 20.1 milyon dolar fazla vererek ihracatın ithalatı karşılama oranı $\% 127.2$ ile tarihinin en yüksek oranına ulaşmıştır. 
Tablo 3. Türkiye'nin Dış Ticaret Dengesi 1928-1939 (Kaynak: TUIKK, s.477.)

\begin{tabular}{|c|c|c|c|}
\hline$\overline{\text { Yil }}$ & $\begin{array}{l}\text { Diş Ticaret Dengesi } \\
\text { (Milyon \$) }\end{array}$ & $\begin{array}{l}\text { İhracatın İthalatı } \\
\text { Oranı \% }\end{array}$ & KarşılamaDış Ticaret Hacmi \\
\hline 1928 & -25.4 & 77.6 & 202 \\
\hline 1929 & -48.7 & 60.6 & 198.4 \\
\hline 1930 & 1.8 & 102.6 & 140.9 \\
\hline 1931 & 0.3 & 100.5 & 120.2 \\
\hline 1932 & 7.3 & 117.8 & 88.7 \\
\hline 1933 & 13 & 128.8 & 103.2 \\
\hline 1934 & 4.2 & 106.2 & 141.8 \\
\hline 1935 & 5.6 & 107.9 & 146.9 \\
\hline 1936 & 20.1 & 127.2 & 167.3 \\
\hline 1937 & 18.7 & 120.6 & 199.8 \\
\hline 1938 & -3.9 & 96.7 & 233.9 \\
\hline 1939 & 7.1 & 107.7 & 192.1 \\
\hline
\end{tabular}

\section{Sonuç}

Türkiye Cumhuriyeti, 1929 Dünya Ekonomik Krizi karşısında Türk parasının değerini yabancı paralar karşısında korumaya çalışmıştır. Bunu sağlamak için çeşitli kanunlar çıkarıldığı gibi yeni kurumlar da kurulmuştur. Alınan tedbirler sayesinde Türk Lirası yabancı paralar karşısında değerini koruyarak ödemeler dengesinin sağlanmasında önemli bir etken olmuştur. Bu bağlamda bankacılık sektörü de cumhuriyetin ilk yıllarından itibaren önem verilen bir husus olmuş, özellikle tarım ve sanayi sektörünü desteklemek adına önemli adımlar atılmıştır. Ancak yeterli sermaye olmaması milli bankacılığın gelişmesini engellemiş sektöre yabancı sermayeni hâkim olmasını sağlamıştır. Ekonomik krizin Türkiye'yi etkisi altına aldığ 1929 yılı itibariyle de yabancı bankaların etkin olduğu bankacılık sistemi ile gerek Türk parasının değerini korumanın gerekse üreticinin nakit ve kredi ihtiyaçlarının karşılanmasının mümkün olmadığı anlaşılmıştır. Devletçilik politikasının benimsendiği bu süreçte geniş kapsamlı devlet yatırımlarının kontrol edilmesi zor olan ve güvenilirliği belli olmayan yabancı bankalar vasıtasıyla finanse edilmesi mümkün görünmemektedir. Bu nedenle alınan tedbirlerle kriz döneminde yabancı banka sayısı büyük oranda azalırken milli banka sayısında artış olmuştur.

Kriz döneminde vergi sisteminde de önemli değişiklikler yapılmıştır. Krizle mücadele edebilmek adına bazı yeni vergiler çıkarıldığı gibi bazı vergilerde de düzenlemeler yapılmıştır. Elbette bu vergilerin çoğu vatan- 
daşa ek yük getirmiştir. Ancak bazı vergilerde krize karşı vatandaşı koruyucu tedbirler alındığı da görülmüştür. Neticede vergiler kriz döneminde hükümetin elini güçlendiren en önemli gelir kaynaklarından biri olmuştur.

Kriz döneminde ihracatın azalması ve Türk parasının değer kaybetmesi dış ticaret açı̆̆ını ortaya çıkarsa da, bu dönemde alınan tedbirler sayesinde özellikle 1930'lu yılların ortalarından itibaren ihracat gelirlerinde önemli bir ivme yakalanmıştır. Böylece ihracatın ithalat karşısında fazla verdiği bir dış ticaret yapısı ortaya çıkmıştır.

Sonuç olarak baktığımızda Türkiye, kriz döneminde almış olduğu mali ve ticari tedbirler sayesinde Türk parasının değerini korumuş ve buna bağlı olarak ödeme dengesini sağlamıştır. Bankacılık ve vergi sistemini krize göre düzenleyerek gelirlerini ve piyasaları kontrol etmeyi başarmıştır. Tüm bu mali düzenlemelere bağlı olarak dış ticaret dengesi sağlandığı gibi elde edilen fazla ile cumhuriyet döneminin önemli atılımları için kaynak sağlanmıştır. Neticede dünyayı etkisi altına alan büyük bir krizle mücadele ederken cumhuriyetin ilanından itibaren en önemli ekonomik politika olan denk bütçe, dengeli dış ticaret hedefine ulaşılmıştır. 


\section{EXTENDED ABSTRACT \\ Financial and Commercial Measures Taken by Turkey Against the World Economic Crisis of 1929 \\ Nedim Sarıüzel \\ Selçuk University}

The world economic crisis of 1929 deeply affected the important forces of the period, especially the United States. Turkey has received at least as much share of this crisis as the major states. Turkey, which built its economic policy on development by supporting private capital in the period 1923-1930, adopted an economic model in which the state was more interventionist with the crisis. The equivalent budget and balanced foreign payment policy of the Atatürk period continued during the crisis process. But in this period, in parallel with the general change in economic policy, the state undertook the task of achieving the goal of an equal and balanced economy. In order to combat the crisis, various measures have been taken to protect Turkish money and ensure the balance of external payments.

If we look at the extent to which Turkey has been affected by the crisis before moving on to the measures it has taken against the crisis, we will see that this is due to the foreign trade deficit and the value of money. Because the world economic crisis has shown its effect with a large drop in raw material prices, which has a negative impact on the prices of Turkey's export products. Thus, as the foreign trade deficit appeared in a short time, the Turkish lira began to depreciate rapidly against foreign currencies. In fact, in this process, Turkey had a high rate of agricultural exports, but due to Turkey's inability to reach the level of production that would meet its foreign trade commitments, the depreciation of Turkish currency accelerated in 1928-1930. As a result of the drought in 1929, the decrease in exports had an effect. In addition, purchases made by the state within the framework of the nationalization policy increased the foreign exchange deficit. In particular, the nationalization of railway lines in the 
concession of foreign companies and the construction of new lines brought a financial burden. On the other hand, the installment of Ottoman debts coincided with this period was an important factor.

In order to protect the value of Turkish currency against foreign currencies, a number of measures have been taken within the framework of protectionist policies since mid-1929. The law on securities and Exchange exchanges and the law on the protection of the value of Turkish money were adopted to control the money market. Efforts in this direction have been initiated after it was seen that it is not possible to protect the value of Turkish currency without the establishment of the central bank. However, it was not until 1930 that the bank was founded that a consortium of Banks was formed. In the following period, the Central Bank was established and in 1931 it took over the task of executing monetary policies from the consortium of banks.

After the economic depression in the banking sector, the Bank of Industry and mines, which was unable to meet the credit needs of the industrialist as the first business, was closed in 1932 and the Industrial Credit Bank of Turkey and the State Industrial Office were established to perform this task. Sümerbank, Etibank and Iller Bank were other important organizations established during this period. The number of foreign banks, which was 34 in 1929, fell to 10 in 1933, and five national banks were established and started operations in the same period.

In addition to the banks established during this period, the market was tried to be controlled by various laws and decrees issued. After the crisis, the economy was forced to borrow high interest rates from merchants and tradesmen who could not receive loans and support from official sources. Bankruptcies increased among merchants and tradesmen who were unable to pay their debts. In order to protect and support small investors from loan sharks, The Law on Lending Money was adopted. In addition, the People's Bank and People's Chests Law were adopted to meet the lowamount credit needs of small shopkeepers and citizens all over the country.

Taxes have also formed an important pillar of the financial measures taken to combat the world economic crisis. Both by making various regu- 
lations on existing taxes and by issuing new taxes, the crisis has been fought. Of course, the situation of the people affected by the crisis has not been ignored when taxing.

Land Tax, Animal Tax, Building Tax, Earnings Tax, Inheritance Tax and Treatment Tax have been amended and brought into line with the crisis period. Economic Depression Tax, Balance Tax, Air Force Assistance Tax and Internal Consumption Tax were the first taxes imposed during the crisis period.

Another area where the government intervened during the crisis was foreign trade. The most important development that enabled the government to take protective measures in this area was the entry into force of the New Customs Tariff law on June 1, 1929. Thus, Turkey was freed from The Binding of the 1916 Customs Tariff, which it agreed to continue for another five years according to the Treaty of Lausanne, and obtained the right to set a new customs tariff. After the adoption of the customs Eve, the first significant change was the power of attorney for Customs and exclusions, established on 29 December 1931 to monitor Customs and exclusions. After a number of laws were passed to prevent smuggling, The General Command of Customs Enforcement was established.

During the crisis, one of the important policies used by the government to establish the balance of foreign trade was to encourage citizens to use domestic goods and save money. In order to increase the use of domestic goods and to spread its savings prevention activities to a wide audience, the National Economics and Savings Society was established on December 12, 1929.

During the crisis, one of the important policies used by the government to establish the balance of foreign trade was to encourage citizens to use domestic goods and save money. In order to increase the use of domestic goods and to spread its savings prevention activities to a wide audience, the National Economics and savings Society was established on December 12, 1929.

Within the framework of these measures taken by Turkey, significant changes have been made to monetary, banking and trade policy and tax system. These changes have also been implemented through agreements with states that have bilateral trade relations. Thus, a more protectionist policy was adopted in the name of combating the crisis. 


\section{Kaynakça / References}

11940 Sayılı Kararname (1931, 16 Kasım). T.C. Resmi Gazete (Sayı 1951). Erişim adresi: https://www.resmigazete.gov.tr/arsiv/1951.pdf

Arazi ve bina iratlarından alınacak vergi miktarı tenzil edilecek. (1931, 11 Haziran). Milliyet, S. 1914, s. 1.

Aysan, M. A. (1980). Atatürk'ün ekonomi politikası. İstanbul: İstanbul Üniversitesi Yayını.

Başvekâlet İstatistik Umum Müdürlüğü. (1939). Mevduat İstatistikleri: Tasarruf Mevduatı, Ticari Mahiyetteki Mevduat 1933-1938. Ankara.

Başvekâlet İstatistik Umum Müdürlüğü. (1940). Mali İstatistikler: Devlet Maliyesi 1932-1939. Ankara: Mehmet İhsan Matbaası.

Başvekâlet İstatistik Umum Müdürlüğü. (1941). Fiat İstatistikleri Başlıca Ecnebi Paralarının Çek ve Efektif Fiatları 1926-1940. İstanbul: Hüsnütabıat Basimevi.

Belediye Bankası Teşkiline Dair Kanun Çıktı. (1933, 12 Haziran). Milliyet, S. 2534, s.1-4.

Belediyeler Bankası Kanunu (1933, 24 Haziran) T.C. Resmi Gazete (Say1: 2435). Erişim adresi: https://www.resmigazete.gov.tr/arsiv/2435.pdf

Bina İratları Kanunu Tebliğ Edildi. (1931, 29 Temmuz). Milliyet, S. 1962, s. 3.

Bina Vergileri. (1932, 20 Eylül). Akşam, S. 5010, s.3.

Boratav, K. (1987). Türkiye iktisat tarihi 1908-1985. İstanbul: Pandora.

Buhran Vergisi Herkese Teşmil Edilmeyecek. (1933, 15 Şubat). Vakit, S. 5425, s.2.

Buhran vergisi serbest meslek erbabından da teşmil ediliyor. (1932, 29 Haziran). Cumhuriyet, S. 2925, s.1.

Dişçiler yeni vergiyi fazla buluyorlar. (1934, 15 Nisan). Haber, S. 703, s.1-7.

Doktorlar ve avukatların kazanç vergisi. (1934, 21 Mart). Milliyet, S. 2914, s.17.

Dünya Buhranı ve Türkiye. (1932, 27 Mart). Cumhuriyet, S. 2834, s.4.

Esnaf ve işçi. (1934, 10 Ekim). Haber, S. 881, s.8.

Etibank Kanunu (1935, 22 Haziran) T.C. Resmi Gazete (Sayı: 3035). Erişim adresi: https://wwww.resmigazete.gov.tr/arsiv/3035.pdf

Findıkoğlu, Z. F. (1967). Kooperasyon sosyolojisi (Nazari Ve Tatbiki Kooperatifçilik Denemesi). İstanbul: Fakülteler Matbaası.

Genel İthalat Rejimi Kararı (1937, 13 Temmuz). T.C. Resmi Gazete (Sayı: 3655). Erişim adresi: https://wwww.resmigazete.gov.tr/arsiv/3655.pdf 
Glasneck, J. (1976). Kemal Atatürk ve Çağdaş Türkiye. Çev. Arif Gelen, Ankara: Onur Yayinları.

Gümrük Muhafaza Memurlarının Askerî Teşkilâta Göre Tensiki Hakkında Kanun (1931, 27 Temmuz) T.C. Resmi Gazete (Sayı: 1858). Erişim adresi: https://www.resmigazete.gov.tr/arsiv/1858.pdf

Gümrük Muhafaza Umum Kumandanlığı Kanunu (1932a, 12 Ocak). T.C. Resmi Gazete (Say1: 2000). Erişim adresi: https://www.resmigazete.gov.tr/arsiv/2000.pdf

Gümrük Tarifesi Kanunu (1929, 1 Temmuz) T.C. Resmi Gazete (Sayı: 1230). https://www.resmigazete.gov.tr/arsiv/1230.pdf

Gümrük ve İnhisarlar Vekâleti Kanunu (1931, 30 Aralık). T.C. Resmi Gazete (Sayı: 1989). Erişim adresi: https://www.resmigazete.gov.tr/arsiv/1989.pdf

Halk Bankası ve Halk Sandıkları Kanunu (1933, 18 Haziran). T.C. Resmi Gazete (Sayı: 2430). Erişim adresi: https://wwww.resmigazete.gov.tr/arsiv/2430.pdf Hava Kuvvetlerine Yardım Vergisi Kanunu (1936, 2 Ocak) T.C. Resmi Gazete (Say1: 3195). Erişim adresi: https://wwww.resmigazete.gov.tr/arsiv/3195.pdf Kaçakçılığın Men ve Takibine Dair Kanun (1932b, 12 Ocak). T.C. Resmi Gazete (Say1: 2000). Erişim adresi: https://wwww.resmigazete.gov.tr/arsiv/2000.pdf

Kaya, Ş. (1940). Türkiye harici ticaret: resmi istatistiklere nazaran tahlil ve mukayese raporu 1930-1938. İstanbul: Güneş Matbaası.

Kazanç Vergisi itirazlar çabuk tetkik edilecek. (1934, 11 Ekim). Akşam, S. 5750, s.3.

Kazanç Vergisi Kanunu (1934, 25 Mart). T.C. Resmi Gazete (Sayı: 2662). Erişim adresi: https://www.resmigazete.gov.tr/arsiv/2662.pdf

Kazanç Vergisi. (1934, 20 Mart). Akşam, S. 5548, s.2.

Kazgan, G. (2004). Tanzimat'tan 21. Yüzyıla Türkiye ekonomisi. İstanbul: Bilgi Üniversitesi Yayınları.

Kepenek, Y. ve Yentürk, N. (1994). Türkiye ekonomisi. İstanbul: Remzi Kitabevi. Keyder, Ç. (1993). Dünya Ekonomisi içinde Türkiye (1923-1929). İstanbul: Tarih Vakfı Yurt Yayınları.

Kocabaşoğlu, U. vd. (2001). Türkiye İş Bankası Tarihi. Ankara: Türkiye İş Bankası Kültür Yayınları.

Köklü, A. (1947). Türkiye'de para meseleleri (1914-1946 Devresinde Para Siyasetimiz ve Paramızın Kıymeti). Ankara: Milli Eğitim Basımevi.

Menkul Kıymetler ve Kambiyo Borsaları Kanunu (1929, 30 Mayıs). T.C. Resmi Gazete (Say1: 1203). Erişim adresi: https://www.resmigazete.gov.tr/arsiv/1203.pdf. 
Merkez Bankası Kanunu (1930, 30 Haziran). T.C. Resmi Gazete (Sayı: 1533). Erişim adresi: https://wwww.resmigazete.gov.tr/arsiv/1533.pdf

Merkez Bankası Kanunu. (1930, 12 Haziran). Cumhuriyet, S. 2189, s.1-2.

Muamele Vergisi Kanunu (1931, 2Ağustos). T.C. Resmi Gazete (Say1: 1862). Erişim adresi: https://www.resmigazete.gov.tr/arsiv/1862.pdf

Nadi, Y. (1930, 13 Haziran). Devlet Bankası. Cumhuriyet, S. 2190, s.1.

Nadi, Y. (1932, 6 Nisan). Asrın Ticareti: "Standard" Usulü. Cumhuriyet, S. 27, s.1.

Nizameddin Ali. (1933, 22 Haziran). Sümerbank. Milliyet, S. 2644, s.1.

Paramızın Hali ve Atisi Emindir. (1930, 21 Şubat). Milliyet, S. 1448, s.1.

Sadrettin, M. (1934, 12 Mart). Buğdayı korumaya devam için. Milliyet, S. 2905, s.1.

Sadrettin, M. (1934, 16 Mart). Kazanç Vergisi. Milliyet, S. 2909, s.1.

Saraçoğlu, F. (2009). 1930-1939 döneminde vergi politikası. Maliye Dergisi, 157, 131-149.

Semiz, Y. (1996). Atatürk Döneminin iktisat politikası milli iktisat ve tasarruf cemiyeti. Konya: Saray Kitabevi.

Serbest Meslek Erbabı da Buhran Vergisi Verecek. (1932, 29 Haziran). Akşam, S. 4927, s.1.

Siirt Mebusu Mahmut. (1931, 8 Ekim). Cumhuriyet Merkez Bankası. Milliyet, S. 2033, s.1.

Sümerbank Kanunu (1933, 11 Haziran). T.C. Resmi Gazete (Sayı: 2424). Erişim adresi: https://www.resmigazete.gov.tr/arsiv/2424.pdf

Şükrü, A. (1934, 30 Mayıs). Buğdayı Korumak. Milliyet, S. 2981, s.1.

Takas Komisyonu Teşkili Hakkında Kanun (1932, 31 Mayıs). T.C. Resmi Gazete (Say1: 2112). Erişim adresi: https://wwww.resmigazete.gov.tr/arsiv/2112.pdf

Tefecilere karşı şiddetli tedbirler alındı. (1933, 9 Haziran). Milliyet, S. 2631, s.16.

Tefecilik yapanlar ağır cezaya çarptırılacak. (1933, 30 Mayıs). Milliyet, S. 2621, s.1-6.

Tekeli, İ. ve İlkin, S. (1982). Uygulamaya geçerken Türkiyede Devletçiliğin oluşumu. Ankara: Orta Doğu Teknik Üniversitesi Yayınları.

Tekeli, İ. ve İlkin, S. (1997). Para ve Kredi Sisteminin Oluşumunda Bir Aşama Türkiye Cumhuriyeti Merkez Bankası. Ankara: T.C. Merkez Bankası Yayınlar1.

Ticaret Mukavelesi ve Modus Vivendi Akdetmeyen Devletler Ülkesinden Türkiye'ye Yapılacak İthalata Memnuiyetler veya Tahdit veyahut 
Takyitler Tatbikine Dair Kanun (1931, 1 Ağustos). T.C. Resmi Gazete (Say1: 1861). Erişim adresi: $\quad$ https://wwww.resmigazete.gov.tr/arsiv/1861.pdf.

Ticarette Tağşişin Men'i ve İhracatın Murakabesi ve Korunması Hakkında Kanun (1930, 19 Haziran). T.C. Resmi Gazete (Say1: 1524). Erişim adresi: https://www.resmigazete.gov.tr/arsiv/1524.pdf.

Türk Parasının Kıymetini Koruma Hakkında Kanun (1930, 25 Şubat). T.C. Resmi Gazete (Sayı: 1433). Erişim adresi: https://www.resmigazete.gov.tr/arsiv/1433.pdf.

Türkiye İstatistik Kurumu. (2009). İstatistik göstergeler 1923-2008. Ankara: TUIKK Yayınları.

Vural, İ. Y. (2008). Atatürk Dönemi maliye politikaları: liberal iktisattan karma ekonomiye. Dumlupınar Üniversitesi Sosyal Bilimler Dergisi, 20, 77-144.

Yeni bir kanunla tefecilik ortadan kaldırılmıştır. ( 1933, 9 Haziran). Vakit, S. 5536, s.1-10.

Yerasimos, S. (1989). Azgelişmişlik Sürecinde Türkiye Dünya Savaşından 19971'e. Çev: Babür Kuzucu, İstanbul: Belge Yayınları.

Zarakolu, A. (1982), 1929/30 Dünya ekonomik krizi karşısında Türk Ekonomisi ve alınan krizle mücadele tedbirleri. Atatürk Dönemi Ekonomi Politikası ve Türkiye'nin Ekonomik Gelişmesi içinde. Ankara: Ankara Üniversitesi Sosyal Bilimler Fakültesi Yayınları, 89-104.

\section{Kaynakça Bilgisi / Citation Information}

Sarıgüzel, N. (2021). Türkiye'nin 1929 Dünya Ekonomik Krizine karşı aldığı mali ve ticari tedbirler. OPUS-Uluslararası Toplum Araştırmaları Dergisi, 18(43), 7055-7081. DOI: 10.26466/opus. 931422. 